\title{
Does quality matter in determining child care prices? Evidence from private child care provision in Turkey
}

\author{
Didem Pekkurnaz ${ }^{1^{*}}$ (D), Meltem A. Aran ${ }^{2}$ and Nazli Aktakke
}

\author{
${ }^{*}$ Correspondence: \\ dpekkurnaz@baskent.edu.tr \\ 1 Department of Economics, \\ Başkent University, Bağlıca \\ Campus, Fatih Sultan \\ Mahallesi, Etimesgut, \\ 06790 Ankara, Turkey \\ Full list of author information \\ is available at the end of the \\ article
}

\begin{abstract}
Child care prices are expected to reflect the quality of provision. However, in contexts where there are high information asymmetries between the users of the services and providers, we may expect this link between quality and prices to be weaker. Turkey is selected for the study as it has a highly regulated child care sector where the costs of accreditation and initial setup are high. However, there is very little on-going supervision and no information provided to users on the quality or ranking of these services. This paper investigates the role of quality in determining private child care prices using a unique provider-level data set collected in five provinces of Turkey. Regression results show that prices are mainly driven by infrastructure quality while human resources and curriculum and materials quality scores that are more likely to have a strong bearing on child development do not have a significant impact on prices.
\end{abstract}

Keywords: Child care quality, Child care prices, Turkey

\section{Introduction}

Investing earlier in a child's life brings a higher return of human capital investment, and interventions in early childhood are more effective than interventions at later ages (Cunha et al., 2006). Child care (it is used interchangeably with early childhood education and care (ECEC)) is a form of non-parental care of children. High-quality child care programs have been shown to have positive effects on child developmental outcomes such as cognitive, health and behavioral and these effects are also long-lasting (see e.g., Abner et al., 2013; Almond \& Currie, 2011; Barnett, 2008; Burchinal et al., 2010; NICHD and Duncan 2003; Nores \& Barnett, 2010). If there is perfect information in the market for child care, we expect that parents would be better able to evaluate the actual quality of the child care environment, and therefore low-quality providers would not survive in the market. However, since parents are not able to observe all the aspects of quality, they would have difficulty in selecting the child care settings that are likely to provide the best developmental outcomes for their children (Karoly, 2009). Thus, most families look for high-quality child care options by taking the price as an important indicator. 
Child care quality is a multidimensional concept such that the safety and health conditions of child care facilities, availability of learning materials, teaching qualifications and caregiver and child interactions determine the quality of care (Slot, 2018). However, parents are not able to discern all dimensions of child care quality as most features are not readily observable to them. Because of this information asymmetry, parents' own judgments about quality may not reflect the actual quality observed by experts on the field (Barraclough \& Smith, 1996; Cryer \& Burchinal, 1997; Cryer et al., 2002). Alternative approaches such as regulations, accreditation, licensing and quality reporting systems are used as remedies to reduce information asymmetry and improve quality in child care settings. Among these approaches, although licensing and regulations are easier to apply and less costly than other alternatives, they generally concentrate on a narrow set of quality attributes that are readily observable such as group size, child-staff ratio and cleanliness of the child care setting and so provide minimum standards for quality (Karoly, 2009). The government has a role in setting and implementing the standards for child care quality through these approaches.

The Turkish child care market is a highly regulated market in terms of infrastructurerelated standards (area of garden space, size of the principal's room, total square meters of indoor and outdoor space per child, etc.) that have been shown to make the price of services less affordable in certain poor urban areas (Aran et al., 2016). On the other hand, a smaller number of requirements exist for human resources and curriculumrelated standards. Infrastructural accreditation standards are strict for initially opening $u p$ the centers. Thus, it is expensive and difficult to open up the facilities, especially for private providers, and those standards also increase their operational costs, primarily through rents (World Bank, 2015). Once centers are set up, there are inspections carried out every several years, but the data coming from these inspections are not transparently shared with parents, and service providers are not ranked or provided with scores/feedback to improve on their quality of provision. Therefore, significant information asymmetries exist in the Turkish child care sector.

In a context like Turkey, where parents and users of services have little information on the differentiated quality of services, and where there is no existing government mechanism that helps users monitor quality, the link between quality and prices may be weaker. Given this regulatory setup and lack of transparency and data sharing in terms of quality of services, we expect that (1) child care prices are mainly driven by infrastructural and locational factors as well as some human resources items that are likely to increase operational expenses and (2) features that are important for child development (though not observed by parents) have little bearing on market prices.

In order to test this hypothesis, this study examines the factors, especially child care quality, associated with child care pricing of private providers in Turkey using a unique child care provider-level data set. It was collected by the World Bank in 2014 for the Supply and Demand for Child Care Services in Turkey study (World Bank, 2015) from five provinces (Denizli, Eskişehir, Gaziantep, Istanbul and Samsun). This study contributes to the literature by examining the link between child care quality and prices using this unique data set for Turkey, a country where the child care market and the role of the government in the supervision of services are very different from cases in developed countries where such studies have been previously carried out. 


\section{Literature review}

Child care quality is generally decomposed into two broad categories: structural quality and process quality. The structural components of quality are generally those that are more easily monitored by the government and include characteristics such as infrastructure, staff-child ratio, education level and experience of staff and physical condition of the child care facility (Burchinal, 2010; Helburn \& Howes, 1996; Slot, 2018). Process quality refers mainly to the presence of developmentally appropriate equipment, materials and learning activities, characteristics of child-staff interactions and teaching style of educators when performing those activities in child care settings (Burchinal, 2010; Helburn \& Howes, 1996; Slot, 2018). Those structural quality attributes are also accepted as inputs into the production of process quality (Mocan, 2007).

The importance of quality on child care prices has been investigated by several studies using the hedonic price approach, whereby the quality measurement is decomposed into its constituent characteristics and estimates are obtained on the contributory value of each characteristic. Blau and Hagy (1998) and Hagy (1998) use this approach to look at the determinants of prices of child care providers. They both find that group size in the centers, one of the most heavily regulated quality variables in the United States (US), has a significant but small effect on prices. Similarly, another heavily regulated quality variable in the US-the staff-to-child ratio-is found to have no significant impact on the prices (Blau \& Hagy, 1998). However, literature gives contradictory results related with the impact of child care quality on prices since a variety of instruments has been used to assess the quality of child care services (see Pianta et al., 2016; Slot, 2018 and Vermeer et al., 2016 for the most commonly used ones). Blau and Mocan (2002) use the Early Childhood Environment Rating Scale (ECERS) and the Infant-Toddler Environment Rating Scale (ITERS) scores across items. They find that higher quality of child care implies higher prices-when no control variables and geographical variables are included and state that this result can emerge when parents are willing to pay more for better quality and cost increases with quality. Since their estimations show that cost increases with higher quality, they argue that their results indicate that parents are willing to pay more for quality. However, this finding contradicts Blau and Hagy (1998). Thus, the authors argue that the main reason for this difference results from the quality measures used in the studies as parents may not be willing to pay more for the elements of quality that are mostly regulated.

In addition to the aforementioned studies, there have been papers that examine the main determinants of child care prices at the county and/or state level using demand and supply-side factors as explanatory variables. Some of those studies on specific states in the US find that variables such as median income, rent and earnings of child care employees are significant determinants of child care prices (Davis \& Li, 2005; Davis et al., 2009; Marrufo et al., 2003; Pekkurnaz, 2015).

Since child care quality is multidimensional, parents are not able to fully observe all elements of quality, leading to information asymmetries in the market (Herbst, 2018; Karoly, 2009). Thus, governments take role in reducing this asymmetry by requiring licensing and regulations to satisfy minimum quality standards in child care settings (Karoly, 2009). Another strand of this literature analyzes the impact of such child care regulations on child care prices (see Artz \& Welsch, 2014; Blau, 2003, 2007; Chipty, 
1995). Among them, Artz and Welsch (2014) use publicly available information about violations, inspections and enforcement actions as indicators of the quality of child care services to examine the impact of this government-provided information on child care prices in three counties in southern Wisconsin. Results show no significant relationship between the quality measures and prices. Thus, as stated by the authors, this might result from the lack of parental knowledge about this quality information, or parents may not find this information convincing. This information asymmetry in the US child care market is also observed in a study by Mocan (2007). Parents try to assess the quality of child care centers based on the observable child care center and room characteristics while these attributes do not necessarily reflect the actual quality of the service, such as the quality of caregiver and child interaction (Mocan, 2007).

\section{Background on child care services in Turkey}

Child care services in Turkey are operated by public and private providers. The total number of pre-primary education institutions increased from 20,675 in the 2006/07 academic year to 26,972 in the 2014/15 academic year and reached 31,246 as of 2017/18 academic year (see Ministry of National Education, 2007, 2015 and 2018). The share of private services was $16.2 \%$ in the $2014 / 15$ academic year and 3.5 percentage points higher than the share in 2006/07 academic year (see Ministry of National Education, 2007, 2015).

Private child care services generally provide high-quality infrastructural attributes than public ones (World Bank, 2015).Nevertheless, maintaining these infrastructural needs are costly and so they are expected to bring about an increase in child care prices. As data from 2014 indicate, there was still unmet demand by households for child care because of the problems related to the accessibility of high quality and affordable child care (Aran et al., 2014; World Bank, 2015).

In Turkey, $71 \%$ of the private providers are accredited by the Ministry of National Education (MoNE), and almost 29\% are accredited by the Ministry of Family and Social Policies (MoFSP). MoFSP gives accreditation only to private providers. In order to be accredited by either of these institutions, a provider must satisfy the compulsory standards listed by MoNE or MoFSP (see World Bank, 2015, p. 102-105 for the full list of standards). In order to be accredited by MoNE 24 requirements for infrastructure and 10 requirements for human resources, curriculum and learning materials should be satisfied. Similarly, there are 21 requirements listed for infrastructure and 7 items listed for human resources, curriculum and learning materials for MoFSP accreditation. In total, infrastructural requirements account for $73 \%$ of total requirements and the remaining requirements are related to human resources (e.g., teachers' educational backgrounds) and curriculum (World Bank, 2015).

In addition, there is no strict regulation or monitoring of child-caregiver interactions, quality of teaching and learning materials, even if these are the developmental cornerstones for children. The government's inspection and supervision processes are active only during the accreditation phase (during setup) and there is minimal continuous supervision of the centers and no mechanisms for signaling the quality levels of centers to users of the services. These facts show us that the child care quality in Turkey does not cover all the necessary child development related standards. 


\section{Data}

The data set for this paper comes from the supply-side service provider quantitative survey from World Bank (2015). The data were collected in five provinces in Turkey (Denizli, Eskişehir, Gaziantep, Istanbul and Samsun) in 2014 from 226 private and 377 public child care providers (details of the data collection procedure are available in World Bank (2015)). All public providers and 163 private providers are accredited by MoNE and the remaining 63 private providers are accredited by MoFSP. The questionnaire includes detailed modules on service provider background, accessibility and enrollment, pricing and costing, staffing, daily routine and activities, family involvement, regulations and standards and finally, observations at the child care facility. ${ }^{1}$

\section{Methods}

Since we have data on various child care characteristics, this data is categorized and used to create four main quality scores: overall quality, infrastructure quality, curriculum and materials quality and human resources quality. Although some items used to generate quality scores are similar to ECERS/ITERS items, they are not exactly the same since ECERS/ITERS are not adopted when constructing the survey questionnaire for providers. In addition to that, we do not observe many process quality variables in this data set, such as child-caregiver interaction, child-child interaction, supervision of caregivers and teacher behaviors. The quality scores are estimated using principal component analysis (PCA) (see Additional file 1: Table S1 for a discussion of the appropriateness of PCA for the study). This method provides a way to transform many correlated variables into a smaller number of principal components which are uncorrelated linear combinations of the variables. We use the first principal component to construct the quality score since it explains most of the variation in the data. The list of variables used to build those quality scores is available in the Additional file 2: Table S2 and their means and standard deviations are available in the Additional file 3: Table S3. The score is then equal to the sum of the multiplication of component coefficient of the first principle component for each variable (which are basically used as weights) with the standardized variable. The equation is as follows:

$$
Q_{i}=\sum_{y}^{Y} \beta_{y} \operatorname{std}\left(X_{y i}\right)
$$

where $Q_{i}$ is the quality score of provider $\mathrm{i}, \operatorname{std}\left(X_{y i}\right)$ is the standardized variable y, and $\beta_{y}$ is the component coefficient of the first principle component for variable $y$. Lastly, these quality scores are further standardized.

In addition to the quality variables, control variables are also included in the analyses. Those variables are a dummy variable for MoNE accreditation, age of the child care center, total enrollment in the center, number of hours the center is open on a Monday (representing one of the busiest days in a week), a dummy variable for

\footnotetext{
${ }^{1}$ Since we are interested in analyzing the private providers' prices, the price data used in this paper is monthly full day prices charged by private providers per student enrolled (Hourly, weekly, per semester or yearly reported prices are converted to monthly prices and half day prices are converted to full day prices by multiplying with $7 / 5$ for private providers).
} 
extended hours of care, number of weeks the center operates in a year, a dummy for free transportation by the center and neighborhood welfare dummies. Providers are asked to categorize the average income level of the institution's immediate area as high, medium and low in the questionnaire. Hence, neighborhood welfare represents the average income level of the surrounding area of the center. Controlling for the income level of the surrounding area (of the child care provider) is important since families might choose specific quality of child care depending on their income level. Thus, ignoring this welfare variable may result in biased estimates of the coefficients of the quality variables. These dummies are used as proxies for the mean income level of the local area because of the unavailability of this data at the province/district level for Turkey. Province dummies are also added in order to control for the time-invariant unobserved locational effects that may affect the pricing strategy of providers. Since the total number of observations for each city is small, we do not estimate price equations separately for cities in order to maximize the total number of observations in regressions. Descriptive statistics of the explanatory variables including the standardized quality scores are available in Table 1.

We first consider the simple correlations between monthly child care prices and quality scores. Fig. 1 shows the plots of the log of monthly prices of private child care providers versus three standardized sub-quality scores (infrastructure, human resources and curriculum and materials quality scores) and the standardized overall quality score that combines all quality variables.

The scatterplot figures show that the infrastructure quality score is positively related to the logged prices of child care while the human resources and curriculum quality scores are not correlated with monthly prices. These plots give us a rough idea about the relationship between prices and quality before we start controlling for other attributes of the providers and locational characteristics.

Child care price equations are estimated via ordinary least squares (OLS) and quantile regression methods for private providers. Firstly, variants of the following price equation are estimated using the OLS approach for private child care providers.

$$
P_{i}=\alpha_{0}+\alpha_{1} Q_{1 i}+\alpha_{2} Q_{2 i}+\alpha_{3} Q_{3 i}+\beta X_{i}+\delta d_{k}+\varepsilon_{i},
$$

where $P_{i}$ is the natural logarithm of monthly full day price of the child care service charged by provider i (i.e., Log monthly price), $Q_{1 i}$ is the standardized infrastructure quality score, $Q_{2 i}$ is the standardized curriculum and materials quality score and $Q_{3 i}$ is the standardized human resources quality score. $X_{i}$ denotes the vector of aforementioned control variables. $d_{k}$ represents the vector of province dummies and $\varepsilon_{i}$ is an idiosyncratic error term. In the alternative specifications of the empirical model written above, instead of single quality scores, the individual variables used to construct those scores are also included in the models.

Secondly, the quantile regression approach (see e.g., Buchinsky, 1998; Koenker, 2005; Koenker \& Bassett, 1978 and Koenker \& Hallock, 2001 for details) is implemented for the models with single quality scores, control variables and with/without province dummies. Quantile regression method reveals relationships between the price variable and the explanatory variables at different points on the conditional distribution of the price variable, 
Table 1 Descriptive statistics

\begin{tabular}{|c|c|c|c|c|c|}
\hline & Variable & Type & Mean & Standard deviation & Range \\
\hline \multirow[t]{2}{*}{ Dependent variable } & Monthly price & Continuous & 784.133 & 364.158 & $21-1600$ \\
\hline & Log monthly price & Continuous & 6.544 & 0.541 & $3.045-7.378$ \\
\hline \multirow{4}{*}{$\begin{array}{l}\text { Standardized quality } \\
\text { scores }\end{array}$} & Overall quality score & Continuous & 0 & 1 & $-8.687-0.310$ \\
\hline & $\begin{array}{l}\text { Infrastructure quality } \\
\text { score }\end{array}$ & Continuous & 0 & 1 & $-8.798-0.259$ \\
\hline & $\begin{array}{l}\text { Curriculum and materi- } \\
\text { als quality score }\end{array}$ & Continuous & 0 & 1 & $-4.410-0.848$ \\
\hline & $\begin{array}{l}\text { Human resources qual- } \\
\text { ity score }\end{array}$ & Continuous & 0 & 1 & $-9.074-1.070$ \\
\hline \multirow[t]{15}{*}{ Other control variables } & $\begin{array}{l}\text { Center is accredited } \\
\text { with MoNE }\end{array}$ & Dummy (0/1) & 0.699 & 0.46 & $0-1$ \\
\hline & Age of the center & Continuous & 7.343 & 5.969 & $0-40$ \\
\hline & $\begin{array}{l}\text { Total enrollment in a } \\
\text { school }\end{array}$ & Continuous & 57.757 & 42.312 & $3-340$ \\
\hline & $\begin{array}{l}\text { Number of hours the } \\
\text { center is open on a } \\
\text { Monday }\end{array}$ & Continuous & 9.993 & 1.244 & $7-12$ \\
\hline & $\begin{array}{l}\text { Center provides service } \\
\text { for extended hours }\end{array}$ & Dummy (0/1) & 0.029 & 0.168 & $0-1$ \\
\hline & $\begin{array}{l}\text { Number of weeks the } \\
\text { center operates in } \\
\text { a year }\end{array}$ & Continuous & 43.335 & 6.648 & $18-48$ \\
\hline & $\begin{array}{l}\text { Center provides free } \\
\text { transportation }\end{array}$ & Dummy (0/1) & 0.127 & 0.334 & $0-1$ \\
\hline & $\begin{array}{l}\text { High neighborhood } \\
\text { welfare }\end{array}$ & Dummy (0/1) & 0.405 & 0.492 & $0-1$ \\
\hline & $\begin{array}{l}\text { Medium neighbor- } \\
\text { hood welfare }\end{array}$ & Dummy (0/1) & 0.555 & 0.498 & $0-1$ \\
\hline & $\begin{array}{l}\text { Low neighborhood } \\
\text { welfare }\end{array}$ & Dummy (0/1) & 0.04 & 0.198 & $0-1$ \\
\hline & Province: Denizli & Dummy $(0 / 1)$ & 0.064 & 0.245 & $0-1$ \\
\hline & Province: Eskisehir & Dummy (0/1) & 0.092 & 0.291 & $0-1$ \\
\hline & Province: Gaziantep & Dummy (0/1) & 0.116 & 0.321 & $0-1$ \\
\hline & Province: Istanbul & Dummy (0/1) & 0.584 & 0.494 & $0-1$ \\
\hline & Province: Samsun & Dummy (0/1) & 0.145 & 0.353 & $0-1$ \\
\hline \multicolumn{3}{|l|}{ Observations } & 173 & 173 & \\
\hline
\end{tabular}

Prices are in Turkish Lira (TRY)

if there are any, while OLS gives us the average relationships using the conditional mean of the price variable. The regression equation for the $\theta$ th quantile is given in Eq. 3 below:

$$
\begin{aligned}
P_{i} & =\alpha_{\theta 0}+\alpha_{\theta 1} Q_{1 i}+\alpha_{\theta 2} Q_{2 i}+\alpha_{\theta 3} Q_{3 i}+\beta_{\theta} X_{i}+\delta_{\theta} d_{k}+\varepsilon_{\theta i} \\
& =Z_{i}^{\prime} \gamma_{\theta}+\varepsilon_{\theta i} \\
& =Q_{\theta}\left(P_{i} \mid Z_{i}\right)+\varepsilon_{\theta i} \text { for } 0<\theta<1 .
\end{aligned}
$$

$\mathrm{Z}$ includes the standardized quality scores, control variables, as well as province dummies and $Q($.$) , represents the conditional quantile of P$ given $Z$. The marginal effects of variables, represented by $\gamma_{\theta}$ can get different values at each quantile. 

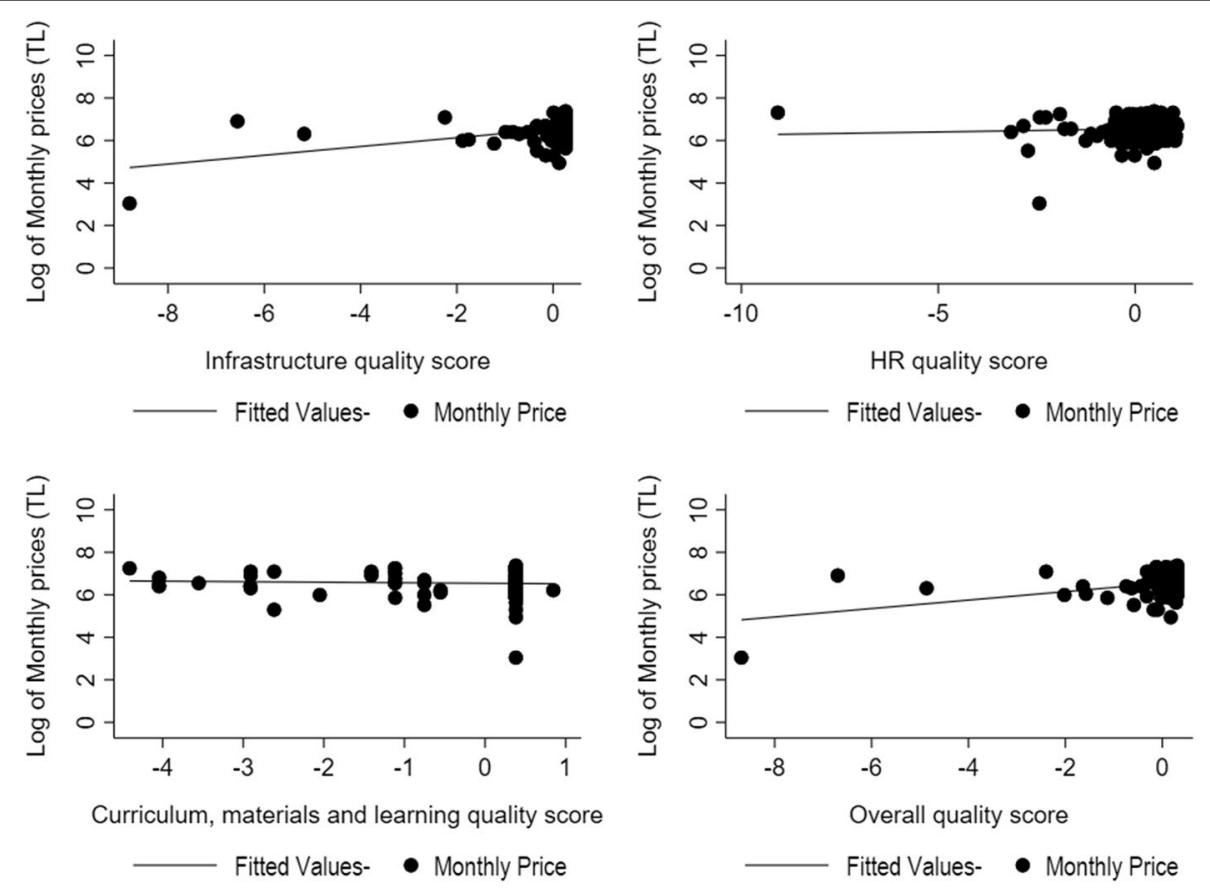

Fig. 1 Log of monthly child care prices and quality scores. HR refers to human resources

\section{Results and discussion}

\section{OLS regression results}

In this section, OLS results of price equations are presented. Six types of models are compared in Table 2 . Model 1 includes the single standardized overall quality score variable, model 2 adds control variables and model 3 includes province dummies along with variables in model 2 . Model 4 disaggregates the overall quality variable into its three sub-components: infrastructure quality, curriculum and materials quality and human resources quality. Model 5 includes control variables as well as quality scores and province dummies are added in model 6 . Since the effects on child care pricing of defining child care quality in the aforementioned sub-components are compared to the effects of an overall quality measure combining all the elements in the sub-components, this study is the result of a subgroup analysis of child care quality, not a sensitivity analysis.

The overall quality score is statistically significant at $10 \%$, with a positive impact on the monthly child care prices charged by the private providers. One unit increase in the standardized overall quality score is, on average, associated with a $19.9 \%$ increase in the monthly child care prices. However, when control variables and province dummies are included the impact of standardized overall quality score disappears (model 2 and model 3 ). As can be seen from model 4, the only significant quality variable is infrastructure quality when the sub-components of overall quality are used. This means that the statistically significant quality effect found in model 1 is mostly driven by the infrastructure quality score. One unit increase in the standardized infrastructure quality score, on average, leads to a $21.4 \%$ increase in the monthly child care prices (model 4 ) at $5 \%$ significance level. However, its effect decreases to $16.3 \%$ and $15.4 \%$, respectively (significant at $10 \%$ level) in models 5 and 6 . Standardized curriculum and materials quality score has a 
Table 2 OLS results for the price equation

\begin{tabular}{|c|c|c|c|c|c|c|}
\hline Variables & 1 & 2 & 3 & 4 & 5 & 6 \\
\hline \multirow[t]{2}{*}{ Overall Quality Score } & $0.199^{*}$ & 0.146 & 0.134 & & & \\
\hline & $(0.115)$ & $(0.101)$ & $(0.092)$ & & & \\
\hline \multirow[t]{2}{*}{ Infrastructure Quality Score } & & & & $0.214^{* *}$ & $0.163^{*}$ & $0.154^{*}$ \\
\hline & & & & $(0.107)$ & $(0.096)$ & $(0.088)$ \\
\hline \multirow[t]{2}{*}{ Curriculum and Materials Quality Score } & & & & -0.058 & -0.053 & $-0.061^{*}$ \\
\hline & & & & $(0.047)$ & $(0.039)$ & $(0.034)$ \\
\hline \multirow[t]{2}{*}{ HR Quality Score } & & & & 0.006 & -0.015 & -0.027 \\
\hline & & & & $(0.056)$ & $(0.048)$ & $(0.042)$ \\
\hline \multirow[t]{2}{*}{ Center is accredited by MoNE } & & $0.253^{* * *}$ & 0.085 & & $0.252^{* * *}$ & 0.090 \\
\hline & & $(0.062)$ & $(0.092)$ & & $(0.062)$ & $(0.091)$ \\
\hline \multirow[t]{2}{*}{ Age of the center } & & -0.014 & -0.014 & & $-0.013^{*}$ & $-0.013^{*}$ \\
\hline & & $(0.008)$ & $(0.008)$ & & $(0.008)$ & $(0.008)$ \\
\hline \multirow[t]{2}{*}{ Total enrollment in a school } & & $-0.002^{*}$ & -0.001 & & -0.002 & -0.001 \\
\hline & & $(0.001)$ & $(0.001)$ & & $(0.001)$ & $(0.001)$ \\
\hline \multirow{2}{*}{$\begin{array}{l}\text { Number of hours the center is open on a } \\
\text { Monday }\end{array}$} & & $0.043^{*}$ & 0.013 & & 0.041 & 0.009 \\
\hline & & $(0.026)$ & $(0.027)$ & & $(0.025)$ & $(0.026)$ \\
\hline \multirow[t]{2}{*}{ Center provides service for extended hours } & & 0.157 & 0.296 & & 0.146 & $0.304^{*}$ \\
\hline & & $(0.155)$ & $(0.182)$ & & $(0.140)$ & $(0.172)$ \\
\hline \multirow{2}{*}{$\begin{array}{l}\text { Number of weeks the center operates in } \\
\text { a year }\end{array}$} & & -0.003 & -0.005 & & -0.000 & -0.001 \\
\hline & & $(0.006)$ & $(0.006)$ & & $(0.005)$ & $(0.005)$ \\
\hline \multirow[t]{2}{*}{ Center provides free transportation } & & $-0.186^{* *}$ & $-0.212^{* *}$ & & $-0.176^{* *}$ & $-0.201^{* *}$ \\
\hline & & $(0.083)$ & $(0.086)$ & & $(0.078)$ & $(0.082)$ \\
\hline \multirow[t]{2}{*}{ High neighborhood welfare } & & $0.518^{* *}$ & $0.548^{* *}$ & & $0.529^{* *}$ & $0.554^{* * *}$ \\
\hline & & $(0.228)$ & $(0.235)$ & & $(0.210)$ & $(0.210)$ \\
\hline \multirow[t]{2}{*}{ Medium neighborhood welfare } & & 0.059 & 0.060 & & 0.067 & 0.061 \\
\hline & & $(0.230)$ & $(0.243)$ & & $(0.209)$ & $(0.215)$ \\
\hline \multirow[t]{2}{*}{ Province: Denizli } & & & $-0.481^{* * *}$ & & & $-0.517^{* * *}$ \\
\hline & & & $(0.170)$ & & & $(0.172)$ \\
\hline \multirow[t]{2}{*}{ Province: Eskisehir } & & & $-0.211^{*}$ & & & $-0.230^{*}$ \\
\hline & & & $(0.123)$ & & & $(0.133)$ \\
\hline \multirow[t]{2}{*}{ Province: Gaziantep } & & & $-0.355^{* *}$ & & & $-0.341^{* *}$ \\
\hline & & & $(0.155)$ & & & $(0.154)$ \\
\hline \multirow[t]{2}{*}{ Province: Samsun } & & & $-0.217^{* *}$ & & & $-0.220^{* *}$ \\
\hline & & & $(0.099)$ & & & $(0.097)$ \\
\hline \multirow[t]{2}{*}{ Constant } & $6.544^{* * *}$ & $6.043^{* * *}$ & $6.610^{* * *}$ & $6.544^{* * *}$ & $5.924^{* * *}$ & $6.483^{* * *}$ \\
\hline & $(0.038)$ & $(0.425)$ & $(0.538)$ & $(0.0381)$ & $(0.398)$ & $(0.502)$ \\
\hline Number of observations & 173 & 173 & 173 & 173 & 173 & 173 \\
\hline$R^{2}$ & 0.135 & 0.436 & 0.488 & 0.157 & 0.454 & 0.510 \\
\hline
\end{tabular}

Robust standard errors are in parentheses ${ }^{* * *} p<0.01,{ }^{* *} p<0.05,{ }^{*} p<0.1$. "Low neighborhood welfare" and "Province: Istanbul" are omitted categories

negative impact on prices and is significant (at 10\% level) only when province dummies are added.

Among control variables, MoNE accreditation is, on average, significantly positively associated with child care prices at $1 \%$ level with an effect of almost $25 \%$ in models 2 and 5. Private providers are either accredited by MoNE or MoFSP as explained in the 
"Background on Child Care Services in Turkey" section. MoNE accreditation requires more items to be satisfied than MoFSP accreditation does (see World Bank, 2015, p. 102-105). This may one of the reasons for higher prices charged by MoNE accredited providers than those accredited by MoFSP. Another reason might be that accreditation by MoNE may give parents more trust (and so more willingness to pay) as MoNE is the national agency of education in the country. However, this significant effect on prices disappears when heterogeneity across provinces is controlled (see Models 3 and 6).

As can be seen from models 2, 3, 5 and 6, child care providers located in high-welfare neighborhoods charge $51.8 \%, 54.8 \%, 52.9 \%$ and $55.4 \%$ higher prices, respectively, than providers from low-welfare neighborhoods. This significant positive association between high-welfare neighborhood and price implies that pass-through from rents or household welfare (and ability to pay) in high-welfare neighborhoods to prices seems to be very strong. This result makes sense since high-welfare neighborhood means a higher standard of living, making the cost of operating in such a neighborhood high for providers.

Providers who offer free transportation charge 18.6\%, 21.2\%, 17.6\% and 20.1\% lower prices, respectively, than providers with paid transportation and no transportation options. As the child care provider's years in business increases by one year, monthly prices are, on average, reduced by almost 1.3\% (models 5 and 6 ). This result differs from the finding by Blau and Hagy (1998), showing that an increase in years of operation is associated with higher prices for center care while it is in accordance with the result for the family day care market in Blau and Hagy (1998). Providing extended hours of care leads to, on average, a $30.4 \%$ increase in child care prices (significant at $10 \%$ level) as shown in model 6. This result may be interpreted using the same logic stated in Hagy (1998) that parents' higher willingness to pay for extended hours of care dominates the economies of scale obtained from extending hours of care provided to families and this turns into higher prices. Child care providers located at Denizli, Eskişehir, Gaziantep and Samsun charge significantly (at 1\%, 10\%, 5\% and 5\%, respectively) lower prices than providers from Istanbul.

In Table 3, all quality attributes forming three quality scores are shown together rather than single quality scores. Columns 2 and 3 in Table 3 add control variables and province dummies, respectively. Some of the components of human resources quality and curriculum and materials quality scores are found to be significant. Sufficient area in the playroom, presence of garden with a soft floor, childproof doors and windows, caregiverto-pupil ratio and percent of teachers with more than five years of experience variables significantly and positively contribute to the child care prices in almost all models.

These results imply that offering higher quality infrastructural components, as well as human resources components that are likely to increase operational costs, are positively associated with prices. The positive association between prices and caregiver-to-pupil ratio is consistent with the findings by Hagy (1998) and Blau and Hagy (1998), although the effect is not significant in Hagy (1998). The positive effect of the experience variable is in contrast with Blau and Hagy (1998), Hagy (1998) and Walker (1992) where they find a negative and insignificant relationship between the two. Our results indicate that providers employing more teachers per child and experienced ( $>=5$ years) teachers charge higher prices as they incur higher operational costs. On the other hand, surfaces made of easy to clean materials, railings on the 
Table 3 OLS results for the price equation (individual quality variables)

\begin{tabular}{|c|c|c|c|}
\hline Variables & 1 & 2 & 3 \\
\hline \multicolumn{4}{|l|}{ Infrastructure quality } \\
\hline \multirow[t]{2}{*}{ Sufficient indoor space } & $1.227^{*}$ & 0.264 & 0.255 \\
\hline & $(0.683)$ & $(0.652)$ & $(0.752)$ \\
\hline \multirow[t]{2}{*}{ Sufficient area in the playroom } & $0.223^{* * *}$ & $0.482^{* * *}$ & $0.461^{* * *}$ \\
\hline & $(0.077)$ & $(0.094)$ & $(0.172)$ \\
\hline \multirow[t]{2}{*}{ Director room } & 0.072 & 0.027 & -0.148 \\
\hline & $(0.277)$ & $(0.282)$ & $(0.337)$ \\
\hline \multirow[t]{2}{*}{ No malodor in the classrooms } & -0.028 & -0.091 & -0.079 \\
\hline & $(0.105)$ & $(0.094)$ & $(0.105)$ \\
\hline \multirow[t]{2}{*}{ Easy to clean materials } & $-0.829^{*}$ & $-1.040^{* * *}$ & $-0.986^{* * *}$ \\
\hline & $(0.457)$ & $(0.248)$ & $(0.281)$ \\
\hline \multirow[t]{2}{*}{ Sufficient number of toilets } & 0.037 & -0.273 & -0.303 \\
\hline & $(0.276)$ & $(0.167)$ & $(0.185)$ \\
\hline \multirow[t]{2}{*}{ Sinks fixed to the walls } & -0.155 & -0.225 & -0.236 \\
\hline & $(0.187)$ & $(0.151)$ & $(0.172)$ \\
\hline \multirow[t]{2}{*}{ Adequate temperature control } & $0.337^{*}$ & 0.278 & 0.301 \\
\hline & $(0.183)$ & $(0.192)$ & $(0.199)$ \\
\hline \multirow[t]{2}{*}{ Sufficient outdoors space } & -0.338 & -0.461 & -0.462 \\
\hline & $(0.546)$ & $(0.363)$ & $(0.393)$ \\
\hline \multirow[t]{2}{*}{ The garden has a soft floor } & 0.084 & $0.980^{*}$ & $1.004^{*}$ \\
\hline & $(0.788)$ & $(0.528)$ & $(0.581)$ \\
\hline \multirow[t]{2}{*}{ Safe outdoors space } & 0.184 & -1.087 & -0.941 \\
\hline & $(0.946)$ & $(0.843)$ & $(0.912)$ \\
\hline \multirow[t]{2}{*}{ Childproof doors and windows } & $1.019^{* *}$ & $1.218^{* * *}$ & $1.174^{* * *}$ \\
\hline & $(0.443)$ & $(0.242)$ & $(0.282)$ \\
\hline \multirow[t]{2}{*}{ Safety covers on electrical outlets } & 0.187 & 0.042 & 0.069 \\
\hline & $(0.233)$ & $(0.112)$ & $(0.111)$ \\
\hline \multirow[t]{2}{*}{ Anchored furniture } & $1.321^{*}$ & 0.753 & 0.820 \\
\hline & $(0.798)$ & $(0.660)$ & $(0.701)$ \\
\hline \multirow[t]{2}{*}{ Railings on the stairs } & $-0.359^{*}$ & $-0.592^{* * *}$ & $-0.535^{* *}$ \\
\hline & $(0.207)$ & $(0.207)$ & $(0.228)$ \\
\hline \multirow[t]{2}{*}{ Cushioned sharp furniture } & 0.125 & 0.186 & 0.163 \\
\hline & $(0.166)$ & $(0.157)$ & $(0.164)$ \\
\hline \multirow[t]{2}{*}{ Railings on the steps for the children with physical disabilities } & 0.156 & 0.074 & 0.087 \\
\hline & $(0.142)$ & $(0.120)$ & $(0.125)$ \\
\hline \multicolumn{4}{|l|}{ Human resources quality } \\
\hline \multirow[t]{2}{*}{ Caregiver pupil ratio } & $0.390^{* *}$ & $0.609 * * *$ & $0.609^{* * *}$ \\
\hline & $(0.186)$ & $(0.157)$ & $(0.149)$ \\
\hline \multirow[t]{2}{*}{ Percent of teachers with university degree } & $0.312^{* * *}$ & 0.120 & 0.134 \\
\hline & $(0.097)$ & $(0.092)$ & $(0.095)$ \\
\hline \multirow[t]{2}{*}{ Percent of teachers with more than 5 years of experience } & $0.199 * *$ & $0.184^{* *}$ & $0.149^{*}$ \\
\hline & $(0.094)$ & $(0.075)$ & $(0.077)$ \\
\hline There is a designated caregiver for each child group & -0.130 & -0.113 & -0.059 \\
\hline & $(0.146)$ & $(0.126)$ & $(0.125)$ \\
\hline There are teachers with training opportunity & -0.036 & 0.070 & 0.057 \\
\hline & $(0.079)$ & $(0.067)$ & $(0.069)$ \\
\hline Curriculum and materials quality & & & \\
\hline Convenient storage for toys & 0.082 & $-0.435^{* *}$ & $-0.509^{* *}$ \\
\hline & $(0.198)$ & $(0.203)$ & $(0.223)$ \\
\hline
\end{tabular}


Table 3 (continued)

\begin{tabular}{|c|c|c|c|}
\hline Variables & 1 & 2 & 3 \\
\hline \multirow[t]{2}{*}{ Parental involvement1 } & 0.121 & 0.039 & -0.010 \\
\hline & $(0.212)$ & $(0.151)$ & $(0.145)$ \\
\hline \multirow[t]{2}{*}{ Parental involvement2 } & $-0.313^{*}$ & $-0.446^{* * *}$ & $-0.443^{* * *}$ \\
\hline & $(0.176)$ & $(0.147)$ & $(0.154)$ \\
\hline \multirow[t]{2}{*}{ Parental involvement3 } & -0.021 & 0.135 & 0.137 \\
\hline & $(0.201)$ & $(0.152)$ & $(0.147)$ \\
\hline \multirow[t]{2}{*}{ There is daily routine in the school } & 0.178 & 0.013 & 0.039 \\
\hline & $(0.112)$ & $(0.123)$ & $(0.145)$ \\
\hline \multirow[t]{2}{*}{ School has a curriculum } & 0.104 & 0.297 & 0.296 \\
\hline & $(0.298)$ & $(0.228)$ & $(0.230)$ \\
\hline \multirow[t]{2}{*}{ Center is accredited by MoNE } & & $0.191 * * *$ & $0.154^{*}$ \\
\hline & & $(0.068)$ & $(0.089)$ \\
\hline \multirow[t]{2}{*}{ Age of the center } & & $-0.018^{* *}$ & $-0.018^{* *}$ \\
\hline & & $(0.008)$ & $(0.008)$ \\
\hline \multirow[t]{2}{*}{ Total enrollment in a school } & & -0.000 & -0.000 \\
\hline & & $(0.001)$ & $(0.001)$ \\
\hline \multirow[t]{2}{*}{ Number of hours the center is open on a Monday } & & 0.033 & 0.025 \\
\hline & & $(0.027)$ & $(0.029)$ \\
\hline \multirow[t]{2}{*}{ Center provides service for extended hours } & & $0.365^{*}$ & $0.473^{* *}$ \\
\hline & & $(0.188)$ & $(0.212)$ \\
\hline \multirow[t]{2}{*}{ Number of weeks the center operates in a year } & & -0.006 & -0.006 \\
\hline & & $(0.006)$ & $(0.006)$ \\
\hline \multirow[t]{2}{*}{ Center provides free transportation } & & $-0.260^{* *}$ & $-0.265^{* *}$ \\
\hline & & $(0.105)$ & $(0.105)$ \\
\hline \multirow[t]{2}{*}{ High neighborhood welfare } & & $0.773^{* * *}$ & $0.771^{* * *}$ \\
\hline & & $(0.162)$ & $(0.170)$ \\
\hline \multirow[t]{2}{*}{ Medium neighborhood welfare } & & $0.278^{*}$ & $0.289^{*}$ \\
\hline & & $(0.158)$ & $(0.168)$ \\
\hline \multirow[t]{2}{*}{ Province: Denizli } & & & -0.183 \\
\hline & & & $(0.180)$ \\
\hline \multirow[t]{2}{*}{ Province: Eskisehir } & & & -0.079 \\
\hline & & & $(0.149)$ \\
\hline \multirow[t]{2}{*}{ Province: Gaziantep } & & & -0.025 \\
\hline & & & $(0.159)$ \\
\hline \multirow[t]{2}{*}{ Province: Samsun } & & & -0.159 \\
\hline & & & $(0.103)$ \\
\hline \multirow[t]{2}{*}{ Constant } & $3.003^{* *}$ & $5.804^{* * *}$ & $5.905^{* * *}$ \\
\hline & $(1.335)$ & $(1.384)$ & $(1.479)$ \\
\hline Number of observations & 173 & 173 & 173 \\
\hline$R^{2}$ & 0.391 & 0.632 & 0.641 \\
\hline
\end{tabular}

Robust standard errors are in parentheses ${ }^{* * *} p<0.01,{ }^{* *} p<0.05,{ }^{*} p<0.1$. "Low neighborhood welfare" and "Province: Istanbul" are omitted categories

stairs, presence of convenient storage for toys and parental involvement 2 (i.e., regularly receiving feedback from parents) variables are all significantly and negatively associated with child care prices in all models. The negative association between prices and receiving regular feedback from families might be a result of two mechanisms: (1) providers are able to lower their prices by using parental time and in-kind 
contributions, and/or (2) receiving feedback from parents puts more pressure on them to lower their prices.

Among control variables, MoNE accreditation, providing service for extended hours and being located in high-welfare and medium-welfare neighborhoods are significantly and positively associated with child care prices while age of the center and 'offering free transportation' have negative effects on child care prices both in models 2 and 3 . These results are in accordance with the findings from Table 2.

\section{Quantile regression results}

We can imagine scenarios where the relationship between quality and prices vary for different levels of monthly child care prices. The OLS figures provided in the above section give the average relationship between the quality variables and the price level. Using quantile regression techniques, we can consider the relationship between quality and prices at different levels on the price spectrum. Using quantile regression techniques also provides more robust estimates in the presence of outliers in the data. Hence, in this section, we focus on quantile regression results and Tables 4 and 5 show quantile regressions for models 5 and 6 represented in Table 2. Results are shown only for the 0.10 , $0.25,0.50,0.75$ and 0.90 quantiles.

Based on Table 4, a striking finding is that both the coefficient and significance of the infrastructure quality score increases at the 0.25 quantile (one of the lowest quartile of prices) compared to the OLS result. That is, one unit increase in this standardized infrastructure quality score is statistically significantly (at 5\% level) associated with a 32.7\% increase in prices (in the 0.25 quantile) while based on OLS the score is significant only at $10 \%$ with an effect of $16.3 \%$. This finding indicates that OLS underestimates the coefficient of infrastructure quality on child care prices at the lower end of the price spectrum. This finding holds true when we add province dummies to the regression as shown in column 2 in Table 5 . In the OLS result, the effect of the infrastructure quality score is $15.4 \%$ with province dummies, while at the lower end of the price spectrum (in the 0.25 quantile), this effect increases to $34.7 \%$ and is statistically significant at $5 \%$.

The implication of this finding is that child care providers that are most likely to be serving poor and middle-class households in the data are also those that are most impacted by the infrastructural regulatory standards and for these providers, the regulations turn into significantly higher prices. This finding is consistent with the main findings from a previous paper on how infrastructure regulations-where they are binding-make provision more costly for private providers in Istanbul (Aran et al., 2016) and may, in turn, make services less affordable for the poorest children living in districts where some of these regulations are hard to fulfil.

The positive association between 'high neighborhood welfare' and prices is in accordance with the result found in Table 2. That is, significant effect of higher neighborhood welfare is not only evident at the average price level, but also at different levels of the price spectrum. Consistent with the finding from Table 2 (Model 5), MoNE accreditation seems to have a positive and statistically significant effect on prices (at almost all levels of the price spectrum in Table 4). However, when province effects are controlled, MoNE accreditation tends to increase prices further only at the higher level of prices (Table 5). 
Table 4 Quantile regression results for the price equation

\begin{tabular}{|c|c|c|c|c|c|}
\hline \multirow[b]{2}{*}{ Variables } & \multicolumn{5}{|c|}{ Quantile of prices } \\
\hline & $Q(0.10)$ & $\mathrm{Q}(0.25)$ & $Q(0.50)$ & $Q(0.75)$ & $Q(0.90)$ \\
\hline \multirow[t]{2}{*}{ Infrastructure Quality Score } & 0.218 & $0.327^{* *}$ & 0.111 & 0.075 & -0.058 \\
\hline & $(0.150)$ & $(0.150)$ & $(0.143)$ & $(0.122)$ & $(0.126)$ \\
\hline \multirow{2}{*}{ Curriculum and Materials Quality Score } & -0.005 & -0.097 & -0.033 & -0.029 & 0.008 \\
\hline & $(0.094)$ & $(0.071)$ & $(0.043)$ & $(0.038)$ & $(0.027)$ \\
\hline \multirow[t]{2}{*}{ HR Quality Score } & 0.055 & 0.041 & -0.027 & -0.062 & -0.027 \\
\hline & $(0.106)$ & $(0.114)$ & $(0.053)$ & $(0.040)$ & $(0.032)$ \\
\hline \multirow[t]{2}{*}{ Center is accredited by MoNE } & 0.023 & $0.222^{*}$ & $0.289^{* * *}$ & $0.268^{* * *}$ & $0.321^{* * *}$ \\
\hline & $(0.126)$ & $(0.119)$ & $(0.095)$ & $(0.089)$ & $(0.114)$ \\
\hline \multirow[t]{2}{*}{ Age of the center } & -0.018 & -0.003 & 0.001 & -0.003 & 0.000 \\
\hline & $(0.016)$ & $(0.015)$ & $(0.006)$ & $(0.006)$ & $(0.006)$ \\
\hline \multirow[t]{2}{*}{ Total enrollment in a school } & -0.003 & -0.000 & -0.001 & -0.001 & $-0.002^{*}$ \\
\hline & $(0.002)$ & $(0.002)$ & $(0.001)$ & $(0.001)$ & $(0.001)$ \\
\hline \multirow[t]{2}{*}{ Number of hours the center is open on a Monday } & 0.050 & 0.061 & 0.036 & 0.026 & -0.011 \\
\hline & $(0.060)$ & $(0.045)$ & $(0.031)$ & $(0.023)$ & $(0.031)$ \\
\hline \multirow[t]{2}{*}{ Center provides service for extended hours } & 0.246 & 0.173 & 0.110 & 0.091 & 0.081 \\
\hline & $(0.251)$ & $(0.265)$ & $(0.272)$ & $(0.234)$ & $(0.193)$ \\
\hline \multirow[t]{2}{*}{ Number of weeks the center operates in a year } & -0.003 & 0.000 & $0.015^{* *}$ & 0.000 & -0.005 \\
\hline & $(0.010)$ & $(0.010)$ & $(0.008)$ & $(0.008)$ & $(0.006)$ \\
\hline \multirow[t]{2}{*}{ Center provides free transportation } & -0.061 & -0.086 & -0.103 & $-0.175^{*}$ & $-0.266^{* * *}$ \\
\hline & $(0.153)$ & $(0.146)$ & $(0.113)$ & $(0.100)$ & $(0.092)$ \\
\hline \multirow[t]{2}{*}{ High neighborhood welfare } & $0.666^{* *}$ & $0.577^{* *}$ & $0.665^{*}$ & $0.747^{* *}$ & 0.847 \\
\hline & $(0.268)$ & $(0.256)$ & $(0.361)$ & $(0.296)$ & $(0.588)$ \\
\hline \multirow[t]{2}{*}{ Medium neighborhood welfare } & 0.300 & 0.154 & 0.082 & 0.230 & 0.476 \\
\hline & $(0.229)$ & $(0.241)$ & $(0.356)$ & $(0.306)$ & $(0.593)$ \\
\hline \multirow[t]{2}{*}{ Constant } & $5.497^{* * *}$ & $5.263^{* * *}$ & $5.128^{* * *}$ & $6.005^{* * *}$ & $6.589^{* * *}$ \\
\hline & $(0.850)$ & $(0.621)$ & $(0.566)$ & $(0.485)$ & $(0.778)$ \\
\hline Number of observations & 173 & 173 & 173 & 173 & 173 \\
\hline Pseudo- $R^{2}$ & 0.300 & 0.201 & 0.277 & 0.383 & 0.321 \\
\hline
\end{tabular}

"Low neighborhood welfare" is the omitted category. $Q(0.10), Q(0.25), Q(0.50), Q(0.75)$ and $Q(0.90)$ represent $0.10,0.25,0.50$, 0.75 and 0.90 quantiles, respectively

Bootstrapped standard errors are in parentheses ${ }^{* * *} p<0.01,{ }^{* *} p<0.05,{ }^{*} p<0.1$

\section{General discussion}

The main finding of this research shows that higher infrastructure quality is associated with higher prices of private services. It is consistently positively correlated with child care prices in all specifications. Infrastructure quality score shows to what extent child care providers satisfy physical, safety and security standards in the child care environment. We can state that fulfilling physical standards as well as some human resources elements that are likely to increase operational costs (such as caregiver-to-pupil ratio) are driving prices up for private providers. However, results indicate that variables such as daily routines and curriculum which are mostly correlated with developmental outcomes of children and most parental involvement variables are not valued in the market for private child care. Mainly two things can explain these findings: (1) regulations on infrastructural items and (2) the lack of a transparent quality monitoring and reporting system in Turkey. 
Table 5 Quantile regression results for the price equation with province dummies

\begin{tabular}{|c|c|c|c|c|c|}
\hline \multirow[b]{2}{*}{ Variables } & \multicolumn{5}{|c|}{ Quantile of prices } \\
\hline & $Q(0.10)$ & $Q(0.25)$ & $Q(0.50)$ & $Q(0.75)$ & $\mathrm{Q}(0.90)$ \\
\hline \multirow[t]{2}{*}{ Infrastructure Quality Score } & 0.168 & $0.347^{* *}$ & 0.020 & 0.099 & 0.001 \\
\hline & $(0.146)$ & $(0.170)$ & $(0.146)$ & $(0.110)$ & $(0.112)$ \\
\hline \multirow{2}{*}{ Curriculum and Materials Quality Score } & -0.034 & -0.049 & -0.011 & -0.034 & 0.009 \\
\hline & $(0.077)$ & $(0.060)$ & $(0.047)$ & $(0.037)$ & $(0.039)$ \\
\hline \multirow[t]{2}{*}{ HR Quality Score } & 0.001 & -0.077 & -0.014 & -0.056 & -0.022 \\
\hline & $(0.100)$ & $(0.083)$ & $(0.047)$ & $(0.038)$ & $(0.040)$ \\
\hline \multirow[t]{2}{*}{ Center is accredited by MoNE } & -0.112 & 0.106 & 0.104 & $0.190^{*}$ & $0.279^{* * *}$ \\
\hline & $(0.134)$ & $(0.137)$ & $(0.115)$ & $(0.112)$ & $(0.098)$ \\
\hline \multirow[t]{2}{*}{ Age of the center } & -0.028 & -0.002 & 0.002 & -0.002 & 0.002 \\
\hline & $(0.019)$ & $(0.016)$ & $(0.008)$ & $(0.007)$ & $(0.007)$ \\
\hline \multirow[t]{2}{*}{ Total enrollment in a school } & -0.002 & 0.001 & -0.000 & -0.001 & $-0.002^{* *}$ \\
\hline & $(0.002)$ & $(0.002)$ & $(0.001)$ & $(0.001)$ & $(0.001)$ \\
\hline \multirow[t]{2}{*}{ Number of hours the center is open on a Monday } & 0.049 & 0.037 & 0.047 & 0.011 & -0.028 \\
\hline & $(0.043)$ & $(0.050)$ & $(0.036)$ & $(0.033)$ & $(0.038)$ \\
\hline \multirow[t]{2}{*}{ Center provides service for extended hours } & 0.433 & $0.631^{*}$ & 0.356 & 0.222 & 0.202 \\
\hline & $(0.312)$ & $(0.381)$ & $(0.253)$ & $(0.226)$ & $(0.274)$ \\
\hline \multirow[t]{2}{*}{ Number of weeks the center operates in a year } & 0.011 & 0.001 & 0.008 & 0.000 & -0.008 \\
\hline & $(0.012)$ & $(0.010)$ & $(0.007)$ & $(0.007)$ & $(0.007)$ \\
\hline \multirow[t]{2}{*}{ Center provides free transportation } & -0.099 & -0.144 & -0.103 & -0.150 & $-0.298^{* * *}$ \\
\hline & $(0.201)$ & $(0.178)$ & $(0.126)$ & $(0.101)$ & $(0.091)$ \\
\hline \multirow[t]{2}{*}{ High neighborhood welfare } & $0.757^{* *}$ & $0.723^{* * *}$ & $0.650^{* * *}$ & $0.605^{* *}$ & 0.510 \\
\hline & $(0.333)$ & $(0.273)$ & $(0.223)$ & $(0.304)$ & $(0.461)$ \\
\hline \multirow[t]{2}{*}{ Medium neighborhood welfare } & 0.379 & 0.270 & 0.044 & 0.119 & 0.125 \\
\hline & $(0.321)$ & $(0.276)$ & $(0.240)$ & $(0.317)$ & $(0.470)$ \\
\hline \multirow[t]{2}{*}{ Province: Denizli } & $-0.493^{*}$ & $-0.680^{* *}$ & $-0.524^{* *}$ & -0.302 & $-0.451^{* *}$ \\
\hline & $(0.297)$ & $(0.304)$ & $(0.256)$ & $(0.209)$ & $(0.182)$ \\
\hline \multirow[t]{2}{*}{ Province: Eskisehir } & -0.237 & $-0.535^{*}$ & -0.171 & -0.140 & -0.040 \\
\hline & $(0.249)$ & $(0.288)$ & $(0.203)$ & $(0.154)$ & $(0.149)$ \\
\hline \multirow[t]{2}{*}{ Province: Gaziantep } & -0.397 & -0.365 & -0.347 & -0.110 & -0.079 \\
\hline & $(0.253)$ & $(0.234)$ & $(0.212)$ & $(0.206)$ & $(0.163)$ \\
\hline \multirow[t]{2}{*}{ Province: Samsun } & $-0.321^{* *}$ & $-0.267^{*}$ & -0.164 & -0.118 & 0.084 \\
\hline & $(0.162)$ & $(0.147)$ & $(0.132)$ & $(0.146)$ & $(0.123)$ \\
\hline \multirow[t]{2}{*}{ Constant } & $5.061 * * *$ & $5.466^{* * *}$ & $5.591^{* * *}$ & $6.383^{* * *}$ & $7.294^{* * *}$ \\
\hline & $(0.780)$ & $(0.943)$ & $(0.538)$ & $(0.606)$ & $(0.835)$ \\
\hline Number of observations & 173 & 173 & 173 & 173 & 173 \\
\hline Pseudo $R^{2}$ & 0.373 & 0.246 & 0.308 & 0.402 & 0.355 \\
\hline
\end{tabular}

Bootstrapped standard errors are in parentheses ${ }^{* *} p<0.01,{ }^{* *} p<0.05,{ }^{*} p<0.1$

"Low neighborhood welfare" and "Province: Istanbul” are omitted categories. Q(0.10), Q(0.25), Q(0.50), Q(0.75) and Q(0.90) represent $0.10,0.25,0.50,0.75$ and 0.90 quantiles, respectively

Firstly, 36.7 percent of private providers accredited by MoNE and MoFSP state that they have difficulties following physical and safety standards (World Bank, 2015). Since these regulations work as barriers to entry for the child care sector, private providers that are able to fulfill the requirements and offer high-quality infrastructure and building conditions experience higher initial setup costs and operational costs (World Bank, 2015). This eventually turns into higher prices for private providers. 
Secondly, because of the multidimensional aspects of the quality of child care services parents, in general, are not able to observe all the elements of quality. Physical and infrastructural conditions, as well as caregiver-pupil ratio, are easy to observe during the visits to child care facilities but the impact of some of those characteristics of child care on child outcomes is generally small (Duncan \& Gibson-Davis, 2006). Even though those characteristics have influences (but small) on child outcomes, they are accepted as inputs to the production of process quality through providing better interactions and teaching environment (Helburn \& Howes, 1996; Slot, 2018). However, interactions between caregiver and child and teaching style of caregiver are not observable to families unless a monitoring and reporting system is available to public. Because of this information asymmetry, parents are, in general, not able to detect high-quality services (Weinraub, 2015). From the demand side investigation by World Bank (2015), it is seen that in Turkey parents' minimum expectations about child care quality concentrate mainly on hygiene, safety and health conditions as well as the quality of human resources and child-caregiver interaction. On the other hand, parents do not value much the characteristics of the child care facility regarding its garden, although it is one of the regulated items and listed as one of the most difficult requirements to fulfil by providers (World Bank, 2015). These findings reveal that what parents would like to get as "quality" is different from what they actually get. This difference is not only due to the regulations on limited features of child care services, but also to the lack of any means of monitoring and reporting of service quality to the public in Turkey. Therefore, teacher training, parental involvement, curriculum and daily routine features (they would also be valued by parents) do not have strong bearing on prices.

\section{Limitations of the study}

This study has some limitations. Firstly, the data set is not nationally representative for Turkey since it only includes private providers from five provinces. Thus, the results cannot be generalized for the child care system in the country. However, as being the only comprehensive data on child care services in Turkey, it makes a substantial contribution to this area. Secondly, the sample size is not large enough to obtain efficient estimates as we employ more variables for the models. Therefore, we present the results with and without additional variables. Thirdly, measurement of quality would be more comprehensive with a data set that includes interactions at the classroom level, which is an important part of process quality. Finally, the data set is cross-sectional as it only covers the information for 2014. Thus, we are not able to observe changes, if any, in the quality of child care services over time. Further data collection efforts in the child care sector in Turkey could focus on process quality indicators as well as measurements over time at the same service providers that would help researchers get better estimates of quality as well as control for provider-level fixed effects over time.

\section{Conclusions}

This study aims to understand the determinants of child care prices in a context where parents have little or no ability to observe all the elements of child care quality and there is no mechanism of signaling quality of child care centers to users of the service by government supervisory bodies. The accreditation process is the only point when service 
providers are subjected to fulfil certain requirements, and the standards imposed on these providers during accreditation are mainly related to infrastructural standards (coupled with some HR minimum qualification requirements).

Our findings show that what families pay for the higher priced child care in these five provinces in Turkey is mainly related to infrastructure quality and location and neighborhood effects (which have a high pass-through to rent prices). Moreover, families are unable to discern other inputs into quality as there is no mechanism that measures and reports quality of service delivery. Given the findings of the paper, we consider it important to make child care quality more observable to parents who are buying these services in order for child care services to reflect actual quality of supervision in terms of the content (human resources and materials) of what is delivered rather than only infrastructure and also to enable parents to "vote with their feet" as they become more able to discern the quality of services. Such interventions when coupled with supply-side subsidies that are allocated on the basis of the number of children benefiting from services can potentially have positive impacts on the quality of child care provided at these centers. Quality Rating and Improvement Systems (QRIS) are used in United States to effectively improve the quality of child care services and make information on quality transparent to the public (Herbst, 2018). Similarly, OFSTED in the United Kingdom is adopted as a system that provides both quantitative and qualitative inputs to parents on center quality based on inspector observations. If a similar system is deployed along with an appropriate child care subsidy policy in Turkey, it may help to both improve the affordability of private child care services by linking subsidies to transparency of information and may also reduce information asymmetries in the market and empower parents to make decisions based on a more multifaceted and dynamic definition of quality than the static version currently employed in Turkey. This kind of policy revision is likely to both reduce information asymmetries in the market and boost quality of service provision as well as increase the affordability of child care services, which are currently not at all subsidized.

\section{Abbreviations}

BA: Bachelor's degree; ECEC: Early childhood education and care; ECERS: Early Childhood Environment Rating Scale; HR: Human resources; ITERS: Infant-Toddler Environment Rating Scale; KMO: Kaiser-Meyer-Olkin; MA: Graduate degree; MoFSP: Ministry of Family and Social Policies; MoNE: Ministry of National Education; OLS: Ordinary least squares; PCA: Principal component analysis; US: United States.

\section{Supplementary Information}

The online version contains supplementary material available at https://doi.org/10.1186/s40723-021-00088-4.

Additional file 1: Table S1. Bartlett and KMO test results.

Additional file 2: Table S2. Explanations for the individual quality attributes.

Additional file 3: Table S3. Summary statistics for the individual quality items.

Acknowledgements

The data used were collected as part of the World Bank project Women's Access to Economic Opportunities in Turkey implemented jointly with the Ministry of Family and Social Policy. The project is funded by the Swedish Government via the World Bank's Umbrella Facility for Gender Equality.

\section{Authors' contributions}

DP contributed to writing and provided methodological approach. MA prepared the questionnaire used for the data collection and contributed in finalizing the paper. NA conducted the data analysis. All authors have read and approved the final manuscript. 


\section{Funding}

The project is funded by the Swedish Government via the World Bank's Umbrella Facility for Gender Equality.

Availability of data and materials

The datasets used during the current study are available from the corresponding author on reasonable request.

\section{Declarations}

\section{Competing interests}

The authors declare that they have no competing interests.

\section{Author details}

'Department of Economics, Başkent University, Bağlıca Campus, Fatih Sultan Mahallesi, Etimesgut, 06790 Ankara, Turkey. ${ }^{2}$ Development Analytics Research and Training Association, 21 Toraman Sokak, Emirgan, Istanbul, Turkey. ${ }^{3}$ Development Analytics Research and Training Association, 21 Toraman Sokak, Emirgan, Istanbul, Turkey.

Received: 28 March 2019 Accepted: 22 August 2021

Published online: 03 September 2021

\section{References}

Abner, K. S., Gordon, R. A., Kaestner, R., \& Korenman, S. (2013). Does child care quality mediate associations between type of care and development? Journal of Marriage and Family, 75, 1203-1217. https://doi.org/10.1111/jomf.12055.

Almond, D., \& Currie, J. (2011). Human capital development before age five. In D. Card \& O. Ashenfelter (Eds.), Handbook of Labor Economics (Vol. 4B, pp. 1315-1486). Elsevier.

Aran, M. A., Immervoll, H., \& Ridao-Cano, C. (2014). Can Child Care Vouchers Get Turkish Mothers Back to Work? Estimating the Employment and Redistributionary Impact of a Demand Side Child Care Subsidy in Turkey. Development Analytics Research Paper Series No. 1401. Retrieved from https://papers.ssrn.com/sol3/papers.cfm?abstract_id= 2533946. Accessed 27 Aug 2021.

Aran, M. A., Munoz-Boudet, A. M., \& Aktakke, N. (2016). Can regulations make it more difficult to serve the poor? The case of child care services in Istanbul, Turkey. Journal of Human Development and Capabilities, 17(4), 558-582. https://doi. org/10.1080/19452829.2016.1225703.

Artz, B., \& Welsch, D. M. (2014). Childcare quality and pricing: Evidence from Wisconsin. Applied Economics, 46, 4276-4289. https://doi.org/10.1080/00036846.2014.955256.

Barnett, W. S. (2008). Preschool education and its lasting effects: Research and policy implications. Boulder and Tempe: Education and the Public Interest Center \& Education Policy Research Unit. Retrieved from https://nepc.colorado. edu/sites/default/files/PB-Barnett-EARLY-ED_FINAL.pdf. Accessed 27 Aug 2021.

Barraclough, S. J., \& Smith, A. B. (1996). Do parents choose and value quality child care in New Zealand? International Journal of Early Years Education, 4(1), 5-26. https://doi.org/10.1080/0966976960040101.

Blau, D. M. (2003). Do child care regulations affect the child care and labor markets? Journal of Policy Analysis and Management, 22, 443-465. https://doi.org/10.1002/pam.10140.

Blau, D. M. (2007). Unintended consequences of child care regulations. Labour Economics, 14, 513-538. https://doi.org/10. 1016/j.labeco.2006.01.003.

Blau, D. M., \& Hagy, A. P. (1998). The demand for quality in child care. Journal of Political Economy, 106, 104-146. https://doi. org/10.1086/250004

Blau, D. M., \& Mocan, H. N. (2002). The supply of quality in child care centers. Review of Economics and Statistics, 84 483-496. https://doi.org/10.1162/003465302320259484.

Buchinsky, M. (1998). Recent advances in quantile regression models: A practical quideline for empirical research. Journal of Human Resources, 33, 88-126. https://doi.org/10.2307/146316.

Burchinal, M., Vandergrift, N., Pianta, R., \& Mashburn, A. (2010). Threshold analysis of association between child care quality and child outcomes for low-income children in pre-kindergarten programs. Early Childhood Research Quarterly, 25, 166-176. https://doi.org/10.1016/j.ecresq.2009.10.004.

Burchinal, M. (2010). Differentiating among measures of quality: Key characteristics and their coverage in existing measures, OPRE Research-to-Policy, Research-to-Practice Brief OPRE 2011-10b, Washington, DC: Office of Planning, Research and Evaluation, Administration for Children and Families, U.S. Department of Health and Human Services. Retrieved from https://www.acf.hhs.gov/sites/default/files/documents/opre/differ_measures.pdf. Accessed 27 Aug 2021.

Chipty, T. (1995). Economic effects of quality regulations in the daycare industry. American Economic Review, 85, 419-424.

Cryer, D., \& Burchinal, M. (1997). Parents as child care consumers. Early Childhood Research Quarterly, 12(1), 35-58. https:// doi.org/10.1016/S0885-2006(97)90042-9.

Cryer, D., Tietze, W., \& Wessels, H. (2002). Parents' perceptions of their children's child care: A cross-national comparison. Early Childhood Research Quarterly, 17(2), 259-277. https://doi.org/10.1016/50885-2006(02)00148-5.

Cunha, F., Heckman, J. J., Lochner, L., \& Masterov, D. V. (2006). Interpreting the evidence on life cycle skill formation. In E. Hanushek \& F. Welch (Eds.), Handbook of the Economics of Education (Vol. 1, pp. 697-812). North-Holland.

Davis, E. E., \& Li, N. (2005). Child care assistance and the market for child care in Minnesota. A Report of the Minnesota Child Care Policy Research Partnership. St Paul, Minnesota: Minnesota Department of Human Services. Retrieved from https://edocs.dhs.state.mn.us/Ifserver/Legacy/DHS-4234-ENG. Accessed 29 Oct 2014.

Davis, E., \& Li, N. (2009). Regional variation in child care prices: A cross-state analysis. The Journal of Regional Analysis and Policy, 39(1), 40-54. 
Davis, E. E., Li, N., Weber, R. B., \& Grobe, D. (2009). Child care subsidies and child care markets: Evidence from three states. Technical Report. Corvallis, Oregon: Oregon Child Care Research Partnership, Oregon State University Family Policy Program. Retrieved from http://health.oregonstate.edu/sites/health.oregonstate.edu/files/sbhs/pdf/Price-StudyFinal2.pdf. Accessed 27 Aug 2021.

Duncan, G. J., \& Gibson-Davis, C. M. (2006). Connecting child care quality to child outcomes. Evaluation Review, 30(5), 611-630. https://doi.org/10.1177/0193841X06291530.

Hagy, A. P. (1998). The demand for child care quality: An hedonic price theory approach. The Journal of Human Resources, 33, 683-710. https://doi.org/10.2307/146338.

Helburn, S., \& Howes, C. (1996). Child care cost and quality. The Future of Children, 6(2), 62-82. https://doi.org/10.2307/ 1602419 .

Herbst, C. M. (2018). The Impact of quality rating and improvement systems on families' child care choices and the supply of child care labor. Labour Economics, 54, 172-190. https://doi.org/10.1016/j.labeco.2018.08.007.

Kaiser, H. F. (1974). An index of factor simplicity. Psychometrika, 39, 31-36. https://doi.org/10.1007/BF02291575

Karoly, L. (2009). Design options for state preschool systems. In Preschool adequacy and efficiency in California: Issues, policy options, and recommendations (pp. 67-92). Santa Monica, CA; Arlington, VA; Pittsburgh, PA: RAND Corporation. Retrieved from https://www.jstor.org/stable/10.7249/mg889pf-wkkf-pew-nieer-wcjvsf-laup.11. Accessed 27 Aug 2021.

Koenker, R. (2005). Quantile regression. Cambridge University Press.

Koenker, R., \& Bassett, G. J. (1978). Regression quantiles. Econometrica, 46, 33-50. https://doi.org/10.2307/1913643

Koenker, R., \& Hallock, K. F. (2001). Quantile regression. Journal of Economic Perspectives, 15, 143-156. https://doi.org/10. 1257/jep.15.4.143

Marrufo, G., O'Brien-Strain, M., \& Oliver, H. (2003). Child Care Price Dynamics in California. Public Policy Institute of California. Retrieved from https://www.ppic.org/content/pubs/report/R_1203GMR.pdf. Accessed 27 Aug 2021.

Ministry of National Education. (2007). National Education Statistics, Formal Education 2006-2007. Ministry of National Education, Strategy Development Presidency, Turkey. Retrieved from https://sgb.meb.gov.tr/meb_ilys_dosyalar/ 2012_12/06020711_meb_istatistikleri_orgun_egitim_2006_2007.pdf. Accessed 27 Aug 2021.

Ministry of National Education. (2015). National Education Statistics, Formal Education 2014/'15. Ministry of National Education, Strategy Development Presidency, Turkey. Retrieved from https://sgb.meb.gov.tr/istatistik/meb_istatistik leri_orgun_egitim_2014_2015.pdf. Accessed 27 Aug 2021.

Ministry of National Education. (2018). National Education Statistics, Formal Education 2017/'18. Ministry of National Education, Strategy Development Presidency, Turkey. Retrieved from https://sgb.meb.gov.tr/meb_iys_dosyalar/2018_ 09/06123056_meb_istatistikleri_orgun_egitim_2017_2018.pdf. Accessed 27 Aug 2021.

Mocan, N. (2007). Can consumers detect lemons? An empirical analysis of information asymmetry in the market for child care. Journal of Population Economics, 20, 743-780. https://doi.org/10.1007/s00148-006-0087-6

National Institute of Child Health and Human Development (NICHD) Early Child Care Research Network, \& Duncan, G. (2003). Modeling the impacts of child care quality on children's preschool cognitive development. Child Development, 74(5), 1454-1475. https://doi.org/10.1111/1467-8624.00617

Nores, M., \& Barnett, W. S. (2010). Benefits of early childhood interventions across the World: (Under) Investing in the very young. Economics of Education Review, 29, 271-282. https://doi.org/10.1016/j.econedurev.2009.09.001

Pekkurnaz, D. (2015). Analysis of state-level prices of child care centers and family child care homes. Iktisat işletme ve Finans, 30, 35-68. https://doi.org/10.3848/iif.2015.348.4409

Pianta, R., Downer, J., \& Hamre, B. (2016). Quality in early education classrooms: Definitions, gaps, and systems. The Future of Children, 26(2), 119-138. Retrieved from https://files.eric.ed.gov/fulltext/EJ1118551.pdf. Accessed 27 Aug 2021.

Slot, P. (2018). Structural characteristics and process quality in early childhood education and care: A literature review. OECD Education Working Papers No. 176. OECD Publishing, Paris. https://doi.org/10.1787/edaf3793-en. Accessed 27 Aug 2021.

Vermeer, H. J., van IJzendoorn, M. H., Cárcamo, R. A., \& Harrison, L. J. (2016). Quality of child care using the environment rating scales: A meta-analysis of international studies. International Journal of Early Childhood, 48(1), 33-60.

Waite, L. J., Leibowitz, A., \& Witsberger, C. (1991). What parents pay for: Child care characteristics, quality and costs. Journal of Social Issues, 47, 33-48. https://doi.org/10.1111/j.1540-4560.1991.tb00286.x.

Walker, J. (1992). New evidence on the supply of child care. Journal of Human Resources, 27, 40-69. https://doi.org/10. 2307/145912.

Weinraub, M. (2015). Child care in America: Research and policy directions. Social Service Review, 89(4), 727-745. https:// doi.org/10.1086/684650

World Bank. (2015). Supply and demand for child care services in Turkey: a mixed methods study. Report-No: 98884-TR. Retrieved from http://documents.worldbank.org/curated/en/114451467999711217/pdf/98884-WP-P146295-Box39 3198B-PUBLIC-Supply-and-Demand-for-Child-Care-Services-in-Turkey.pdf. Accessed 27 Aug 2021.

\section{Publisher's Note}

Springer Nature remains neutral with regard to jurisdictional claims in published maps and institutional affiliations. 